in vivo $35: 1017-1026(2021)$

doi:10.21873/invivo.12345

\title{
Impact of Smoking on the Survival of Patients With High-risk HPV-positive HNSCC: A Meta-analysis
}

\author{
MOONEF ALOTAIBI ${ }^{1,2^{*}}$, VALERIA VALOVA ${ }^{1 *}$, TONI HÄNSEL ${ }^{1}$, CARMEN STROMBERGER $^{3}$, \\ GRZEGORZ KOFLA ${ }^{4}$, HEIDI OLZE ${ }^{1}$, IRIS PIWONSKI ${ }^{5}$, ANDREAS ALBERS $^{6}$, \\ SEBASTIAN OCHSENREITHER ${ }^{7,8}$ and ANNEKATRIN COORDES ${ }^{1}$ \\ ${ }^{1}$ Department of Otorhinolaryngology, Head and Neck Surgery (CVK and CCM), \\ Charité-Universitätsmedizin Berlin, Corporate Member of Freie Universität Berlin, \\ Humboldt-Universität zu Berlin, and Berlin Institute of Health, Berlin, Germany; \\ ${ }^{2}$ King Fahad Medical City, Department of Otorhinolaryngology, \\ Head and Neck Surgery, Riyadh, Kingdom of Saudi Arabia; \\ ${ }^{3}$ Department of Radiooncology (CVK), Charité-Universitätsmedizin Berlin, Corporate Member of Freie Universität Berlin, \\ Humboldt-Universität zu Berlin, and Berlin Institute of Health, Berlin, Germany; \\ ${ }^{4}$ Department of Oncology $(C V K)$, Charité-Universitätsmedizin Berlin, Corporate Member of Freie Universität Berlin, \\ Humboldt-Universität zu Berlin, and Berlin Institute of Health, Berlin, Germany; \\ ${ }^{5}$ Institute of Pathology, Charité-Universitätsmedizin Berlin, Corporate Member of Freie Universität Berlin, \\ Humboldt-Universität zu Berlin, and Berlin Institute of Health, Berlin, Germany; \\ ${ }^{6}$ Department of Otorhinolaryngology (CBF), Charité-Universitätsmedizin Berlin, \\ Corporate Member of Freie Universität Berlin, Humboldt-Universität zu Berlin, \\ and Berlin Institute of Health, Berlin, Germany; \\ ${ }^{7}$ Department of Oncology (CBF), Charité-Universitätsmedizin Berlin, Corporate Member of Freie Universität Berlin, \\ Humboldt-Universität zu Berlin, and Berlin Institute of Health, Berlin, Germany; \\ ${ }^{8}$ Charité Comprehensive Cancer Center, Berlin, Germany
}

\begin{abstract}
Background/Aim: High risk Human papillomavirus (hr-HPV) and smoking are independant risk factors for head and neck squamous cell carcinomas (HNSCC). While hr$H P V^{+} H N S C C$ has a better prognosis than smokingassociated HNSCC no systematic data are yet available about the combined risk. Patients and Methods: We performed a meta-analysis to assess the overall survival of HNSCC patients relative to the $h r-H P V$ and smoking status. A literature review up to November 2019 was conducted in PubMed and Cochrane Library using the search terms 'HPV,
\end{abstract}

This article is freely accessible online.

*These Authors contributed equally to this study.

Correspondence to: Annekatrin Coordes, MD Ph.D., CharitéUniversitätsmedizin Berlin, corporate member of Freie Universität Berlin, Humboldt-Universität zu Berlin, and Berlin Institute of Health, Department of Otorhinolaryngology, Head and Neck Surgery, Campus Virchow Klinikum, Augustenburger Platz 1, 13353 Berlin, Germany. Tel: +49 30450555602, Fax: +49 30450555970,e-mail: annekatrin.coordes@charite.de

Key Words: HNSCC, smoking, HPV, p16, PCR, ISH.
Smoking and HNSCC'. Results: Nine out of 748 articles were included, 1,436 out of 2,080 patients were $\mathrm{hr}-\mathrm{HPV}^{+}$. The prevalence of $h r-H P V^{+}$smokers was $36 \%$. The meta-analysis showed a significantly better 5-year overall survival for $\mathrm{HPV}^{+}$ non-smokers compared to smokers with risk ratio of 1.94 (95\% confidence intervaI=1.46-2.58). Conclusion: Smoking is a negative prognostic factor for overall survival in patients with $h r-H P V^{+} H N S C C$ and should thus be an important part of staging and treatment.

Head and neck cancer is the sixth most common cancer worldwide. Approximately 630,000 new cases are diagnosed annually resulting in more than 350,000 deaths per year. Head and neck cancer accounts for approximately 3-4\% of all malignancies in Europe and the United States $(1,2)$. More than $90 \%$ of these cases are head and neck squamous cell carcinomas (HNSCC) (3). Despite their anatomic proximity, HNSCC are a heterogeneous group of tumor entities with differences in etiology, diagnostic and therapeutic approaches as well as prognosis (3). The risk of developing HNSCC is associated with several factors. It is well accepted that HNSCC is etiologically associated with excessive tobacco and alcohol consumption. Both smoking and drinking are important risk factors and have a 
synergistic effect (4). Furthermore, infection with high-risk human papilloma viruses (hr-HPV) have been identified as a the second major causative agent (5). Approximately $40 \%$ of all HNSCCs are reported to be $\mathrm{hr}^{-\mathrm{HPV}^{+}}$, as well as approximately $70 \%$ of oropharyngeal squamous cell carcinomas (OPSCCs) (6). HPV-16, HPV-18, HPV-31 and HPV-33 are classified as hr- HPV. HPV-16 is the most common HPV subtype and is associated with $86-92 \%$ of all $\mathrm{HPV}^{+} \mathrm{HNSCCs}(5,6)$. From an epidemiological perspective, the incidence of smoking-associated HNSCC is declining, while that of hr-HPV-induced cancer is increasing, especially in younger patients (7).Moreover, the underlying cause of HNSCC, i.e. toxins such as tobacco and alcohol, or hr$\mathrm{HPV}^{+}$, leads to significant differences not only in etiology, but also in prognosis; $\mathrm{Hr}_{-} \mathrm{HPV}^{+}$status being associated with an improved prognosis. Accordingly, several studies suggested a survival difference of up to $26.9 \%$ between hr$\mathrm{HPV}^{+}$and $\mathrm{HPV}^{-} \mathrm{HNSCC}(8)$. Because hr-HPV ${ }^{+}$tumors differ from and have a more favorable prognosis than $\mathrm{HPV}^{-}$ HNSCC, the recently released Eighth Edition of the American Joint Committee on Cancer created a separate staging algorithm for hr-HPV ${ }^{+}$OPSCC, distinguishing it from $\mathrm{HPV}^{-}$OPSCC. $\mathrm{Hr}-\mathrm{HPV}^{+}$OPSCC that used to be designated as 'advanced stage' is now categorized as 'lower stage', which gives a much more accurate survival prediction $(9,10)$. Smoking, on the other hand, is correlated with poor prognosis. The negative impact of smoking on survival has been well documented (11-13). The 5-year overall survival (OS) rate for never-smokers compared with current-/former smokers is $77.7 \%$ vs. $57.5 / 58.1 \%$ respectively (14). Consequently, our goal was to assess how these two independent prognostic factors interact with each other. To our knowledge, no meta-analysis of survival according to combined HPV/smoking status has been performed. The aim of the current study was to perform a meta-analysis on the survival of patients in these distinct groups and to compare smoking and non-smoking hr-HPV ${ }^{+}$groups.

\section{Patients and Methods}

Literature search. We conducted a comprehensive search looking for published literature that evaluated survival of HNSCC patients according to both hr-HPV and smoking status in the PubMed (http://www.ncbi.nlm.nih.gov/pubmed) and Cochrane Library (https://www.cochranelibrary.com) databases. This search included articles published up to $12 / 26 / 2019$. The following search terms were used: 'HPV, smoking, head and neck cancer'. Additionally, we checked references quoted in original or review articles that may not have been found in the database during the initial literature search. Our search strategy was performed according to the Preferred Reporting Items for Systematic Reviews and MetaAnalyses and logged in the Prospective Register of Systematic Reviews (15). We screened all search results and included studies of patients with HNSCC, investigating survival rates according to HPV and smoking status. When abstracts met our inclusion criteria, the articles were read in detail. Exclusion criteria were: Patient survival information not reported, evaluation of survival based on only one marker (HPV or smoking) or the survival of HPV and smoking status was not combined (e.g. both parameters were assessed separately), non-HNSCC primary cancer (e.g. precancerous lesions, esophageal cancer, lung cancer, skin cancer), cell culture or animal models, systematic reviews or case reports and articles written in a language other than English or German. Finally, this meta-analysis included studies with the following criteria: (i) Proportion of the HNSCC subgroups smoking versus nonsmoking; (ii) numerical survival data for the subgroups [5-year overall survival (OS) or Kaplan-Meier curves of OS by subgroup].

Study selection and data extraction. Two Authors (A.M. and V.V) independently selected the studies using the inclusion and exclusion criteria. Relevant data from all eligible publications were extracted: First author's name, study design, study time, sample number, gender, tumor location, HPV detection method, smoking definition, number of patients in the smoking and non-smoking hr-HPV ${ }^{+}$groups. The 5year OS rate was extracted from the Kaplan-Meier curve using GraphClick (Version 3.0.3, Arizona Software 2010, www.arizonasoftware.ch/graphclick). In case of discrepancies, findings were reanalyzed and discussed until consensus was reached.

Statistical analysis. The 5-year OS of the smoking and non-smoking groups were tested using the risk ratio (RR). The summary RR was estimated including the 95\% confidence interval (CI). The heterogeneity was tested using a chi-squared-based Q test; a $p$-value greater than 0.05 means homogeneity. The existence of heterogeneity was evaluated by using the $\mathrm{I}^{2}$ index in the meta-analysis, which was represented as a percentage value between 0 and 100. We initially applied a fixed-effects model (Mantel-Haenszel method and chisquared test) to the data. When there was significant heterogeneity, we used the random-effects model (DerSimonian-Liard method). We compared the RR of the 5-year OS of the two groups using a forest plot. The funnel plot examined publication bias. For all statistical analysis, we used R Version 3.5.1: A language and environment for statistical computing [R Foundation for Statistical Computing, $R$ Core Team (2018), Vienna, Austria].

Risk of bias. Publication bias was assessed using a funnel plot. After formulating a review question in a hypothetical randomized trial (target trial), the risk of bias was analyzed for each study using the ROBINS-I tool (16). The tool includes seven domains: Confounding, selection of participants for the study (preintervention), classification of intervention (at intervention), deviation from intended interventions, missing data, measurements of outcome, selection of the reported results (post-intervention). The risk of bias analysis was performed independently by two Authors (T.H. and V.V.). All eligible publications were analyzed in detail. Relevant information was extracted to assess the risk of bias in each of the aforementioned domains using the classifications low, moderate, serious or critical risk of bias. Conflicting results were discussed to reach a consensus.

\section{Results}

Literature search. A total of 748 publications were identified. After multiple assessment phases only nine publications met our inclusion criteria (Figure 1), with total of 2,080 patients 

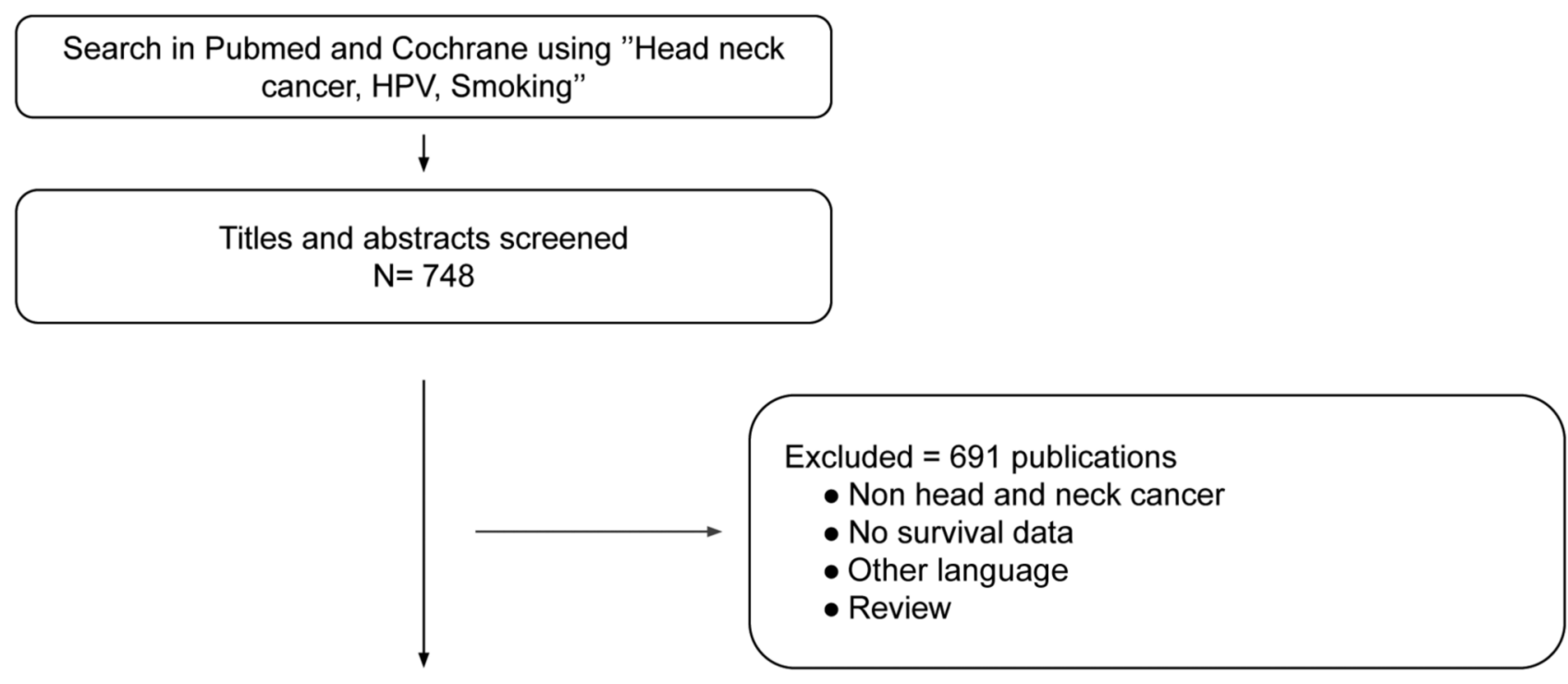

\section{Full-text articles assessed} $\mathrm{N}=57$

\section{Studies included in the meta analysis $\mathrm{N}=9$}

$(11,17,18,19,20,21,22,23,24)$

Figure 1. Flow diagram for the literature search to investigate the impact of smoking in patients according to PRISMA criteria (15).

(mean=231), 1,663 (80\%) male and $417(20 \%)$ female. However, only $\mathrm{HPV}^{+}$patients were included in our study, representing 1,436 patients (range per study=46-484 patients). All nine included studies were cohort studies. The main characteristics of the identified studies are summarized in Table I $(11,17-24)$. A total of $367(36 \%)$ were HPV $^{+}$ smokers and $656(64 \%)$ were $\mathrm{HPV}^{+}$non-smokers. Five studies investigated only $\operatorname{OPSCC}(17,19,21,23,24)$, three studies included patients with $\operatorname{HNSCC}(11,20,22)$, and one study reported patients with carcinoma of unknown primary (18). Three studies were performed in Europe $(11,17,18)$, five studies in North America (20-24), and one study in Asia (19). For determination of HPV states, six studies used the hr-HPV surrogate marker p16 followed by HPV detection using HPV polymerase chain reaction (PCR) or in-situ hybridization (ISH) for DNA detection $(11,17-19,23,24)$. In three studies, HPV was detected using HPV PCR or ISH without studying the p16 status (20-22).

Meta-analysis. All nine studies investigated the 5-year OS of the two hr-HPV ${ }^{+}$HNSCC smoking and nonsmoking subgroups (Figure 2). $\mathrm{Hr}_{-} \mathrm{HPV}^{+}$non-smoking patients had a better prognosis compared with hr-HPV ${ }^{+}$smoking patients (no significant heterogeneity, $p=0.83$, fixed-effect model: $\mathrm{RR}=1.94,95 \% \mathrm{CI}=1.46-2.58)$.

Subgroup analysis. The sub-meta-analyses according to tumor locations included OPSCC and HNSCC other than 
Table I. Characteristics of the included studies with patients with high-risk human papilloma virus (HPV)-positive head and neck squamous carcinoma (HNSCC).

\begin{tabular}{|c|c|c|c|c|c|c|c|c|c|c|c|c|}
\hline \multirow[b]{2}{*}{$\begin{array}{l}\text { Authors } \\
\text { (Ref) }\end{array}$} & \multirow[b]{2}{*}{$\begin{array}{c}\text { No. } \\
\text { of } \\
\text { patients }\end{array}$} & \multirow[b]{2}{*}{$\begin{array}{l}\text { Smokers } \\
\text { definition }\end{array}$} & \multirow[b]{2}{*}{$\begin{array}{c}\text { Non- } \\
\text { smokers }\end{array}$} & \multirow[b]{2}{*}{$\begin{array}{l}\text { Study } \\
\text { years }\end{array}$} & \multirow[b]{2}{*}{ Country } & \multirow[b]{2}{*}{$\begin{array}{c}\text { Mean age } \\
\text { (range), } \\
\text { years }\end{array}$} & \multirow[b]{2}{*}{$\begin{array}{l}\text { Male: } \\
\text { female }\end{array}$} & \multirow[b]{2}{*}{$\begin{array}{l}\text { Tumor } \\
\text { location }\end{array}$} & \multirow[b]{2}{*}{$\begin{array}{l}\text { UICC } \\
\text { stage }\end{array}$} & \multicolumn{2}{|r|}{ HPV } & \multirow[b]{2}{*}{ Smoking } \\
\hline & & & & & & & & & & Subtype & $\begin{array}{l}\text { Detection } \\
\text { method }\end{array}$ & \\
\hline $\begin{array}{l}\text { Hafkamp et al. } \\
2008 \text { (17) }\end{array}$ & 81 & 22 & 10 & 1992-2001 & NL & $\begin{array}{c}58.9 \\
(39-87)\end{array}$ & $59: 22$ & $\begin{array}{l}\text { Oropha- } \\
\text { rynx }\end{array}$ & I-IV & 16 & $\begin{array}{c}\text { HPV DNA ISH } \\
\text { and P16 IHC }\end{array}$ & $\begin{array}{c}\geq 1 \text { Cigarette } \\
/ \text { day }\end{array}$ \\
\hline $\begin{array}{l}\text { Tribius et al. } \\
2012 \text { (18) }\end{array}$ & 63 & 9 & 142 & 2002-2011 & $\mathrm{DE}$ & $\begin{array}{c}58 \\
(42-85)\end{array}$ & $48: 15$ & $\begin{array}{c}\text { CUP } \\
\text { head and } \\
\text { neck }\end{array}$ & III-IV & 16,33 & $\begin{array}{c}\text { HPV DNA PCR } \\
\text { and P16 IHC }\end{array}$ & $\begin{array}{l}\text { Previous or } \\
\text { current } \\
\text { smoker }\end{array}$ \\
\hline $\begin{array}{l}\text { Rhie et al. } \\
2015 \text { (19) }\end{array}$ & 58 & 26 & 9 & $2002-2007$ & $\mathrm{KR}$ & $\begin{array}{c}61.6 \\
(45-82)\end{array}$ & $50: 8$ & $\begin{array}{l}\text { Oropha- } \\
\text { rynx }\end{array}$ & I-IV & $\ddagger$ & $\begin{array}{c}\text { HPV DNA PCR } \\
\text { and P16 IHC }\end{array}$ & $\begin{array}{c}\geq 1 \text { Pack- } \\
\text { year }\end{array}$ \\
\hline $\begin{array}{l}\text { Stucken } \text { et al. } \\
2016(20)\end{array}$ & 55 & 13 & 112 & 2007-2011 & US & $\begin{array}{c}59.2 \\
(41-80)\end{array}$ & $47: 8$ & $\begin{array}{l}\text { Oropha- } \\
\text { rynx and } \\
\text { larynx }\end{array}$ & I-IV & --- & HPV DNA PCR & $\begin{aligned} \geq 10 \text { Pack- } & \text { years }\end{aligned}$ \\
\hline $\begin{array}{l}\text { Descamps } \\
\text { et al. } \\
2016 \text { (11) }\end{array}$ & 218 & 10 & 7 & --- & BEL & $\begin{array}{c}59 \\
(21-88)\end{array}$ & $173: 45$ & HNSCC & II-IV & $\#$ & $\begin{array}{l}\text { HPV DNA PCR } \\
\text { and P16 IHC }\end{array}$ & $\begin{array}{l}\text { Current } \\
\text { smoker }\end{array}$ \\
\hline $\begin{array}{l}\text { Platek et al. } \\
2016 \text { (21) }\end{array}$ & 120 & 20 & 66 & 2008-2015 & US & $\begin{array}{c}58.5 \\
(36-85)\end{array}$ & $96: 24$ & $\begin{array}{l}\text { Oropha- } \\
\text { rynx }\end{array}$ & II-IV & 16,18 & HPV DNA ISH & $\begin{array}{l}\text { Current } \\
\text { smoker }\end{array}$ \\
\hline $\begin{array}{l}\text { Peterson et al. } \\
2016(22)\end{array}$ & 687 & 88 & 52 & $2008-2013$ & US & $\begin{array}{c}61 \\
(---)\end{array}$ & $504: 183$ & HNSCC & I-IV & --- & HPV DNA PCR & $\begin{array}{c}\text { Current } \\
\text { (including } \\
\text { smokers } \\
\text { who quit } \\
\text { within } \\
\text { previous } \\
12 \text { months) }\end{array}$ \\
\hline $\begin{array}{l}\text { Kompelli et al. } \\
2019 \text { (23) }\end{array}$ & 314 & 85 & 97 & 2008-2016 & US & $\begin{array}{c}--- \\
(52-68)\end{array}$ & $262: 52$ & $\begin{array}{l}\text { Oropha- } \\
\text { rynx }\end{array}$ & I-IV & --- & $\begin{array}{l}\text { HPV DNA ISH } \\
\text { and P16 ISH }\end{array}$ & $\begin{array}{c}\text { Heavy } \\
\text { smokers } \\
(>20 \text { pack- } \\
\text { years })\end{array}$ \\
\hline $\begin{array}{l}\text { Xiao et al. } \\
2019 \text { (24) }\end{array}$ & 484 & 94 & 390 & 2001-2015 & US & $\begin{array}{l}58.1 \\
(---)\end{array}$ & $424: 60$ & $\begin{array}{l}\text { Oropha- } \\
\text { rynx }\end{array}$ & I-III & --- & $\begin{array}{c}\text { HPV DNA ISH } \\
\text { and P16 IHC }\end{array}$ & $\begin{array}{l}\text { Current } \\
\text { (including } \\
\text { smokers } \\
\text { who quit } \\
\text { within } \\
3 \text { months) }\end{array}$ \\
\hline
\end{tabular}

---: No information available; OPSCC: oropharyngeal squamous cell carcinoma; CUP: cancer of unknown primary; IHC: immunohistochemistry; ISH: in

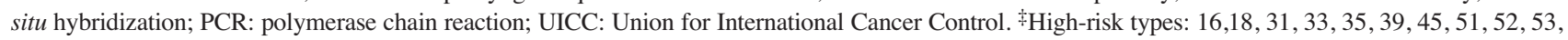
56, 58, 59, 66, 68; low-risk types: 6, 11, 34, 40, 42, 43, 44, 54 and 70; \#types 6, 11, 16, 18, 31, 33, 35, 39, 45, 51, 52, 53, 56, 58, 59, 66, 67 and 68.

OPSCC (OPSCC: no significant heterogeneity, $p=0.83$; fixed effect model, $\mathrm{RR}=1.86,95 \% \mathrm{CI}=1.36-2.54$, and HNSCC without OPSCC: no significant heterogeneity, $p=0.38$; fixed effects model: $\mathrm{RR}=2.23$; 95\% $\mathrm{CI}=1.07-4.65$ ). In both sub analyses, RR and CI were essentially unaltered compared with the major meta-analyses of the complete data set.

The sub-meta-analyses for HPV proof showed comparable results to the major meta-analyses (ISH HPV DNA PCR/ISH and p16: no significant heterogeneity, $p=0.91$; fixed effect model, RR=1.68; 95\% CI=1.19-2.38, and HPV DNA PCR or ISH without p16: no significant heterogeneity, $p=0.68$, fixed effects model, $\mathrm{RR}=2.58,95 \% \mathrm{CI}=1.59-4.20$ ).
Sensitivity analysis. The parameters of $50 \%$ of the most recent studies (no significant heterogeneity, $p=0.59$; fixed effects model, $\mathrm{RR}=1.97,95 \% \mathrm{CI}=1.45-2.68)(11,21-24)$ confirmed the results of the whole meta-analysis with the whole data set.

Publication bias and risk of bias assessment. The funnel plot shape did not reveal any obvious evidence of asymmetry (Figure 3). Egger's test showed no significant publication bias $(p=0.68)$. The risk of bias was assessed using the Risk of Bias in Non-randomized Studies - of Interventions (ROBINS)-I tool, a tool designed specifically to assess the risk of bias in systematic reviews (25). The mapping of 


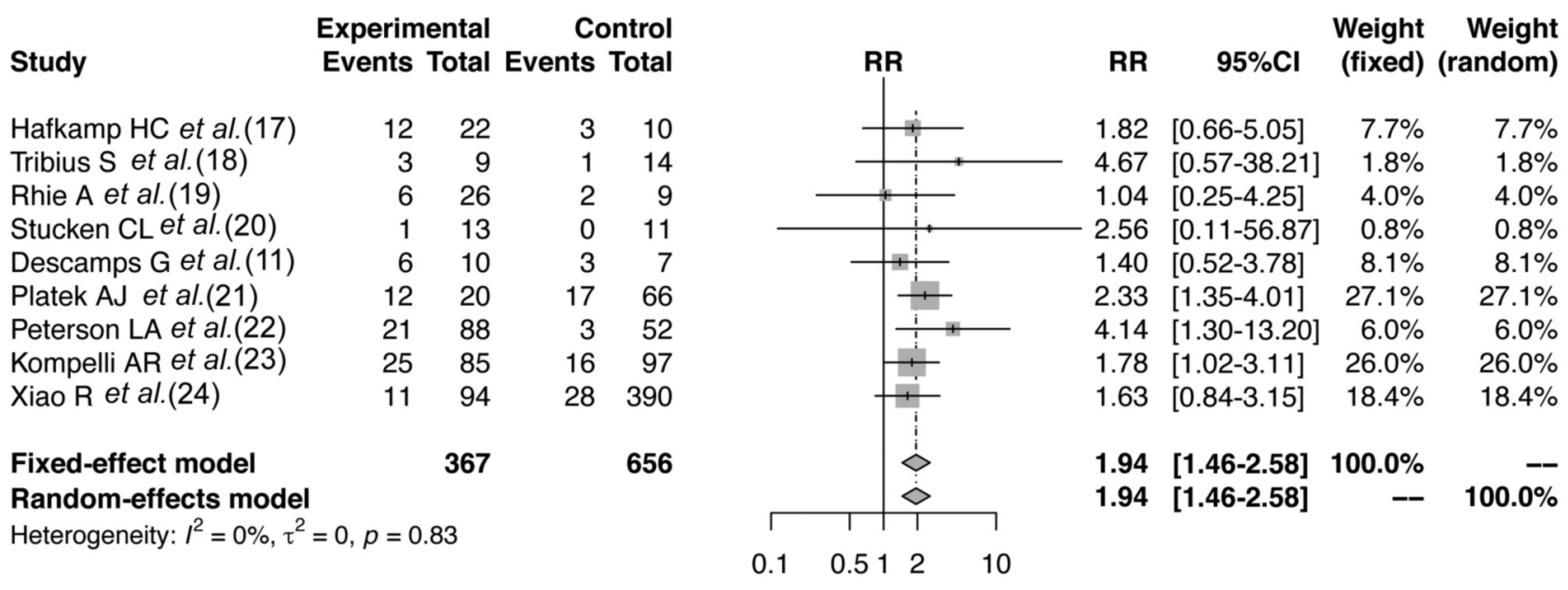

Figure 2. Forest plot of the meta-analysis comparing the 5-year survival of smoking (experimental) and non-smoking (control) patients. CI: Confidence intervaI; RR: risk ratio.

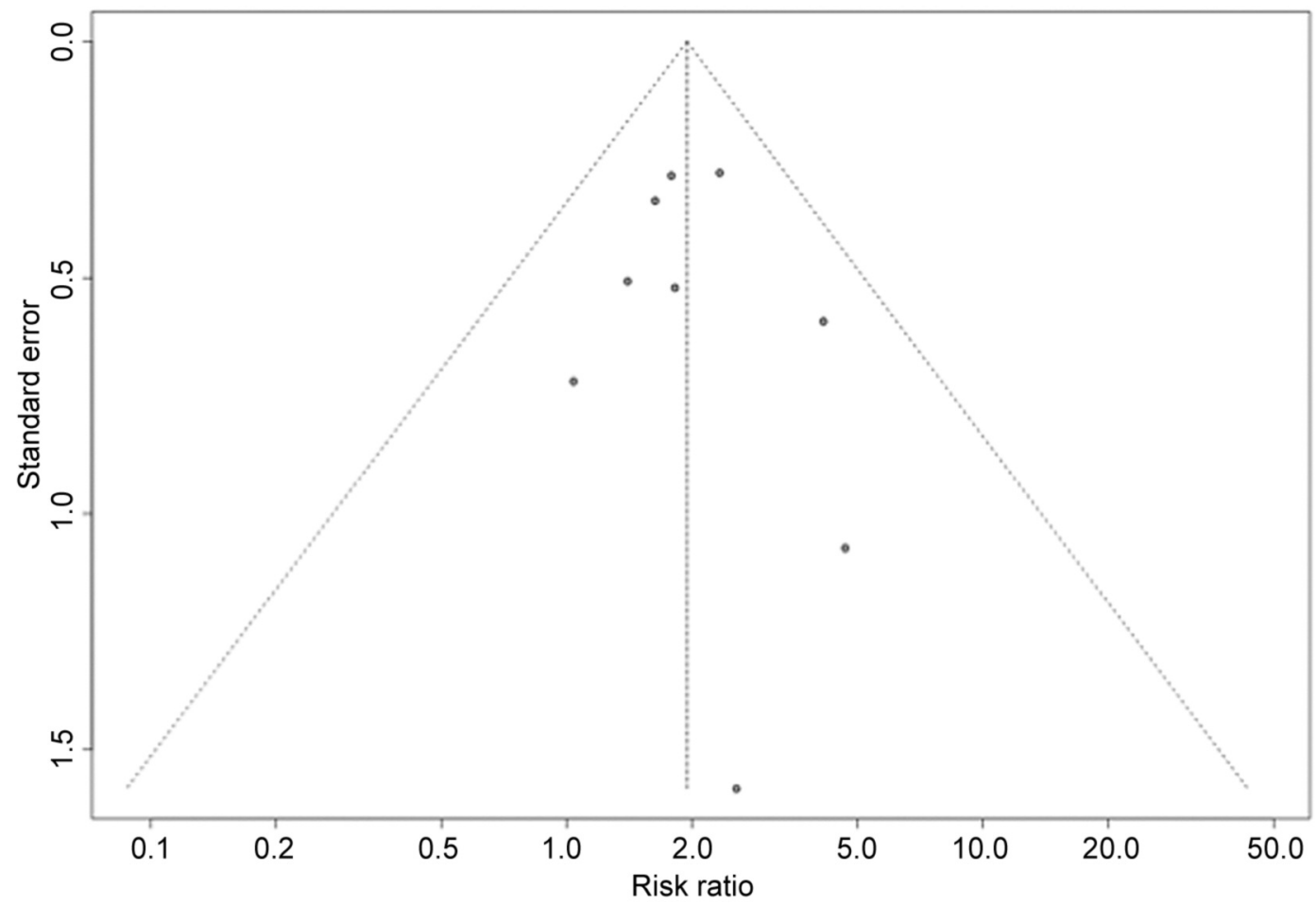

Figure 3. Funnel plot of the meta-analysis of smokers and non-smokers with high-risk human papilloma virus-positive head and neck squamous carcinoma.

domain-level judgements is shown in Table II. Confounding domains included age, gender, co-morbidities and TNM classification. Alcohol consumption, surgery, radiotherapy and chemotherapy were defined as hypothetical cointerventions in the pre-defined target trial. Usually, no controlling method was applied for all criteria which led to the judgement of moderate to high risk of bias in any included study. The wide variety of criteria for patient inclusion in all studies regarding HPV detection method, HPV subtype and tumor sublocalization of HNSCC resulted in moderate to serious risk of bias. p16 testing followed by DNA ISH or PCR was considered the gold standard for HPV 
Table II. Risk of bias analysis.

\begin{tabular}{|c|c|c|c|c|c|c|c|}
\hline \multirow[b]{2}{*}{ Authors (Ref) } & \multicolumn{7}{|c|}{ Risk of bias due to } \\
\hline & Confounding & $\begin{array}{l}\text { Selection of } \\
\text { participants }\end{array}$ & $\begin{array}{c}\text { Classification of } \\
\text { interventions }\end{array}$ & $\begin{array}{l}\text { Deviations from } \\
\text { intended } \\
\text { interventions }\end{array}$ & $\begin{array}{c}\text { Missing } \\
\text { data }\end{array}$ & $\begin{array}{c}\text { Measurement } \\
\text { of outcome }\end{array}$ & $\begin{array}{l}\text { Selection of } \\
\text { reported } \\
\text { results }\end{array}$ \\
\hline $\begin{array}{l}\text { Hafkamp et al. } \\
2008 \text { (17) }\end{array}$ & Serious & Moderate & Moderate & NI & Moderate & Low & Low \\
\hline $\begin{array}{l}\text { Tribius et al. } \\
2012(18)\end{array}$ & NI & Moderate & Serious & NI & Low & Low & Low \\
\hline $\begin{array}{l}\text { Rhie et al. } \\
2015 \text { (19) }\end{array}$ & NI & Serious & Serious & NI & Low & Low & Low \\
\hline $\begin{array}{l}\text { Stucken } \text { et al. } \\
2016 \text { (20) }\end{array}$ & Serious & Moderate & Serious & NI & Moderate & Low & Low \\
\hline $\begin{array}{l}\text { Descamps et al. } \\
2016 \text { (11) }\end{array}$ & NI & Moderate & Moderate & NI & Moderate & Low & Low \\
\hline $\begin{array}{l}\text { Platek et al. } \\
2016 \text { (21) }\end{array}$ & Serious & Serious & Low & NI & Serious & Low & Low \\
\hline $\begin{array}{l}\text { Peterson et al. } \\
2016 \text { (22) }\end{array}$ & Serious & Moderate & Low & Serious & Serious & Low & Low \\
\hline $\begin{array}{l}\text { Kompelli et al. } \\
2019 \text { (23) }\end{array}$ & Moderate & Serious & Serious & Serious & Serious & Low & Serious \\
\hline $\begin{array}{l}\text { Xiao et al. } \\
2019(24)\end{array}$ & Moderate & Serious & Low & Serious & Low & Low & Low \\
\hline
\end{tabular}

NI: No information.

detection and all high-risk HPV subtypes. The HNSCC sublocalizations would have been included in the analysis in an ideal trial. Furthermore, there was a lack of consistent definition of the intervention group 'smoker'. Some authors defined smoking using standardized measures such as packyears, while others focused on the timely aspect and defined a smoker as a patient who actively/currently smokes. Serious risk of bias was determined in the 'deviation of intended intervention' domain if there was evidence of imbalance of co-interventions among the sub-groups, e.g. higher alcohol consumption in connection with smoking. Moreover, missing data can introduce bias if the same HPV detection methods are not applied to all patients. The measurement of the OS outcome was judged as low-risk of bias in all studies and the selection of reported results carried generally low to moderate risk of bias.

\section{Discussion}

Many studies have investigated HNSCC patient outcomes according to HPV or smoking status. It is known that hr$\mathrm{HPV}^{+}$cancers tend to have better outcomes than HPVnegative ones and that smokers usually have a worse prognosis than non-smokers (8-12). Recently Chen et al. published a systematic review showing that all included studies reported that smoking was associated with worse outcomes in hr-HPV ${ }^{+}$cancer (26). Variability of the reported studies regarding reported outcomes and smoking metrics prohibited further analyses. Yet to our knowledge, there has never been a meta-analysis of data and results regarding prognosis of patients with hr-HPV ${ }^{+}$HNSCC based on smoking status. Our meta-analysis compares the outcome of smokers and non-smokers with hrHPV ${ }^{+}$HNSCC. $^{-}$

The analysis showed that smoking plays an important prognostic role in HNSCC, even in the presence of HPV. Our results suggest that non-smokers with $\mathrm{hr}_{-} \mathrm{HPV}^{+} \mathrm{HNSCC}$ have a better 5-year OS compared to their smoking counterparts. Others showed an increased hazard ratio for hr-HPV smokers (27-29). Further studies examined the diseasespecific and disease-free survival (30-34). Going back to the pathogenesis of the HNSCC, we can find two different pathways for its carcinogenesis. In HPV-associated HNSCC, infection with hr-HPV-types leads to an increased expression of E6 and E7, which degrade and inactivate p53 and enhance expression of retinoblastoma protein, which causes overexpression of p16 $(35,36)$. On the other hand, HPV HNSCCs are associated with smoking and alcohol, and exposure to carcinogenic substances such as tobacco-specific nitrosamines that lead to $p 53$ mutation $(37,38)$. However, in $\mathrm{hr}_{-} \mathrm{HPV}^{+}$carcinomas, smoking is an independent risk factor for reduced treatment efficiency and OS (39-41). The significant negative impact of smoking on prognosis might be associated with increased smoking-related comorbidities, such as pulmonary and cardiovascular diseases, therefore 
contributing to a worse survival chance after treatment and increased mortality. Furthermore, studies have shown that smoking increases tumor aggressiveness in cancer cells by stimulation proliferation, angiogenesis, migration, invasion and reducing the response to cytotoxic cancer agents such as chemo- or radiotherapy $(42,43)$. House et al. recently showed that $m i R-133 a-3 p$ is a target of smoking-induced changes in patients with $\mathrm{HPV}^{+}$OPSCC and alters the expression (44). Therefore, recording the smoking status should be an important part of staging and treatment even in patients with hr-HPV ${ }^{+}$HNSCC to predict individual patient risk (45). This also highlights the importance of smoking cessation programs for patients who are actively undergoing treatment as a smoking habit is a potentially modifiable adverse risk factor that might lead to improved outcomes possibly even after diagnosis. The Eighth Edition of the American Joint Committee on Cancer TNM classification distinguishes p16-associated OPSCC from p16- OPSCC (9). The negative impact of smoking is not taken into account in the present classification (39).

HPV detection methods also play an important role. p16 is used as a surrogate marker for the detection of hr-HPV in HNSCC, and p16 immunohistochemistry (IHC) has a sensitivity of $94 \%$ and specificity of $82-83 \%$. HPV DNA PCR has a sensitivity of $97-98 \%$ and specificity of $84-87 \%$, whilst HPV DNA ISH has a sensitivity of $85-88 \%$ and specificity of $83-88 \%(46,47)$. Therefore, the combination of p16 IHC followed by HPV PCR or ISH remains a gold standard for HPV detection in HNSCC to confirm the HPVrelated etiology of HNSCC because, as previously demonstrated, $\mathrm{p}^{+} 6^{+}$HNSCC with HPV-independent carcinogenesis may exist at a low percentage (10). In the present sub-meta-analysis, six out of nine studies used HPV DNA PCR or ISH to confirm the etiology of HPV-associated HNSCC in patients with $16^{+}$IHC (Table I). Even the submeta-analysis including the three studies using only HPV DNA PCR or ISH confirmed the results shown using the whole data set. However, this detection strategy does not confirm p16-associated carcinogenesis and there is the possibility that HPV DNA may also have been an innocent bystander (in cases with p16 ${ }^{-}$HNSCC) (10).

There are some limitations to our study: (a) This metaanalysis is based on data extracted from published literature and not from individual patient data. (b) All included studies were found to carry moderate to serious risk of bias. The vast majority of publications were retrospective cohort studies/non-randomized, controlled trials. These types of studies have greater susceptibility to bias. An important factor to be considered is the role of confounding factors and co-interventions. One problem was the different definitions of smoking (risk of bias analysis). Apart from smoking, there are other factors which also play an important role in prognoses and outcomes of patients with HNSCC such as comorbidities, tumor stage, therapy regimes (e.g. surgery, chemotherapy or radiation). Some studies included different subsites of $\operatorname{HNSCC}(11,20,22)$, and others focused on OPSCC only $(17,19,21,23,24)$.

This heterogeneity in patient selection should be noted because in patients with OPSCC, the impact of HPV in tumorigenesis is accepted. In other sub-localizations, there is no difference for HNSCC with confirmed p16/HPV detection, and HPV detection is therefore not required.

\section{Conclusion}

Smoking plays a significant role in the prognosis of patients with hr-HPV ${ }^{+}$HNSCC. Smokers with hr-HPV ${ }^{+}$HNSCC $^{-}$ have worse survival outcomes compared to hr-HPV nonsmokers. Smoking status should be an important part of staging and be considered when tailoring the treatment strategy even for patients with HPV-associated HNSCC, since these patients are at possible risk of undertreatment.

\section{Conflicts of Interest}

The Authors declare that they have no conflicts of interest in regard to this study.

\section{Authors' Contributions}

Moonef Alotaibi conducted the systematic review, collected and analyzed the data, wrote the main article. Valeria Valova collected and analyzed the data, conducted the risk of bias analysis, wrote the main article. Toni Hänsel conducted and supervised the risk of bias analysis, revised the main article. Carmen Stromberger revised the main article. Grzegorz Kofla revised the main article. Heidi Olze revised the main paper. Iris Piwonski revised the main article. Andreas Albers revised the main article. Sebastian Ochsenreither revised the main article. Annekatrin Coordes designed the review, conducted the systematic review and supervised the work. All Authors commented on the article at all stages.

\section{Acknowledgements}

The Authors would like to thank Ulrich Gauger from Private Statistical Office, Berlin, Germany.

\section{References}

1 Parkin DM, Bray F, Ferlay J and Pisani P: Global cancer statistics, 2002. CA Cancer J Clin 55(2): 74-108, 2005. PMID: 15761078. DOI: 10.3322/canjclin.55.2.74

2 Siegel RL, Miller KD and Jemal A: Cancer statistics, 2019. CA Cancer J Clin 69(1): 7-34, 2019. PMID: 30620402. DOI: $10.3322 /$ caac. 21551

3 Vigneswaran $\mathrm{N}$ and Williams MD: Epidemiologic trends in head and neck cancer and aids in diagnosis. Oral Maxillofac Surg Clin North Am 26(2): 123-141, 2014. PMID: 24794262. DOI: 10.1016/j.coms.2014.01.001 
4 Blot WJ, McLaughlin JK, Winn DM, Austin DF, Greenberg RS, Preston-Martin S, Bernstein L, Schoenberg JB, Stemhagen A and Fraumeni JF, Jr.: Smoking and drinking in relation to oral and pharyngeal cancer. Cancer Res 48(11): 3282-3287, 1988. PMID: 3365707. DOI: $10.1038 /$ sj.bjc.6603713

5 Dayyani F, Etzel CJ, Liu M, Ho CH, Lippman SM and Tsao AS: Meta-analysis of the impact of human papillomavirus (hpv) on cancer risk and overall survival in head and neck squamous cell carcinomas (hnscc). Head Neck Oncol 2: 15, 2010. PMID: 20587061. DOI: 10.1186/1758-3284-2-15

6 Abogunrin S, Di Tanna GL, Keeping S, Carroll S and Iheanacho I: Prevalence of human papillomavirus in head and neck cancers in european populations: A meta-analysis. BMC Cancer 14: 968, 2014. PMID: 25515630. DOI: 10.1186/1471-2407-14-968

7 Tinhofer I, Johrens K, Keilholz U, Kaufmann A, Lehmann A, Weichert W, Stenzinger A, Stromberger C, Klinghammer K, Becker ET, Dommerich S, Stolzel K, Hofmann VM, Hildebrandt B, Moser L, Ervens J, Bottcher A, Albers A, Stabenow R, Reinecke A, Budach V, Hoffmeister B and Raguse JD: Contribution of human papilloma virus to the incidence of squamous cell carcinoma of the head and neck in a european population with high smoking prevalence. Eur J Cancer 51(4): 514-521, 2015. PMID: 25623438. DOI: 10.1016/j.ejca. 2014.12.018

8 Li H, Torabi SJ, Yarbrough WG, Mehra S, Osborn HA and Judson B: Association of human papillomavirus status at head and neck carcinoma subsites with overall survival. JAMA Otolaryngol Head Neck Surg 144(6): 519-525, 2018. PMID: 29801040. DOI: 10.1001/jamaoto.2018.0395

9 Lydiatt WM, Patel SG, O'Sullivan B, Brandwein MS, Ridge JA, Migliacci JC, Loomis AM and Shah JP: Head and neck cancersmajor changes in the american joint committee on cancer eighth edition cancer staging manual. CA Cancer J Clin 67(2): 122-137, 2017. PMID: 28128848. DOI: $10.3322 /$ caac. 21389

10 Albers AE, Qian X, Kaufmann AM and Coordes A: Meta analysis: Hpv and p16 pattern determines survival in patients with hnscc and identifies potential new biologic subtype. Sci Rep 7(1): 16715-16715, 2017. PMID: 29196639. DOI: 10.1038/ s41598-017-16918-w

11 Descamps G, Karaca Y, Lechien JR, Kindt N, Decaestecker C, Remmelink M, Larsimont D, Andry G, Hassid S, Rodriguez A, Khalife M, Journe F and Saussez S: Classical risk factors, but not hpv status, predict survival after chemoradiotherapy in advanced head and neck cancer patients. J Cancer Res Clin Oncol 142(10): 2185-2196, 2016. PMID: 27370781. DOI: 10.1007/s00432-016-2203-7

12 De Cicco R, de Melo Menezes R, Nicolau UR, Pinto CAL, Villa LL and Kowalski LP: Impact of human papillomavirus status on survival and recurrence in a geographic region with a low prevalence of hpv-related cancer: A retrospective cohort study. Head Neck 42(1): 93-102, 2020. PMID: 31633252. DOI: 10.1002/hed.25985

13 Mirghani H, Leroy C, Chekourry Y, Casiraghi O, Auperin A, Tao Y, Nguyen F, Caroline E, Breuskin I, Plana AM, Hartl D, Janot F, Temam S, Gorphe P and Blanchard P: Smoking impact on hpv driven head and neck cancer's oncological outcomes? Oral Oncol 82: 131-137, 2018. PMID: 29909887. DOI: 10.1016/ j.oraloncology.2018.05.007

14 Abrahao R, Anantharaman D, Gaborieau V, Abedi-Ardekani B, Lagiou P, Lagiou A, Ahrens W, Holcatova I, Betka J, Merletti F,
Richiardi L, Kjaerheim K, Serraino D, Polesel J, Simonato L, Alemany L, Agudo Trigueros A, Macfarlane TV, Macfarlane GJ, Znaor A, Robinson M, Canova C, Conway DI, Wright S, Healy CM, Toner M, Cadoni G, Boccia S, Gheit T, Tommasino M, Scelo $\mathrm{G}$ and Brennan P: The influence of smoking, age and stage at diagnosis on the survival after larynx, hypopharynx and oral cavity cancers in europe: The arcage study. Int J Cancer 143(1): 32-44, 2018. PMID: 29405297. DOI: 10.1002/ijc.31294

15 Moher D, Liberati A, Tetzlaff J and Altman DG for the PRISMA group: Preferred reporting items for systematic reviews and meta-analyses: The prisma statement. BMJ 339: b2535, 2009. PMID: 19622551. DOI: 10.1136/bmj.b2535

16 Sterne JA, Hernan MA, Reeves BC, Savovic J, Berkman ND, Viswanathan M, Henry D, Altman DG, Ansari MT, Boutron I, Carpenter JR, Chan AW, Churchill R, Deeks JJ, Hrobjartsson A, Kirkham J, Juni P, Loke YK, Pigott TD, Ramsay CR, Regidor D, Rothstein HR, Sandhu L, Santaguida PL, Schunemann HJ, Shea B, Shrier I, Tugwell P, Turner L, Valentine JC, Waddington $\mathrm{H}$, Waters E, Wells GA, Whiting PF and Higgins JP: Robins-i: A tool for assessing risk of bias in non-randomised studies of interventions. BMJ 355: i4919, 2016. PMID: 27733354. DOI: 10.1136/bmj.i4919

17 Hafkamp HC, Manni JJ, Haesevoets A, Voogd AC, Schepers M, Bot FJ, Hopman AH, Ramaekers FC and Speel EJ: Marked differences in survival rate between smokers and nonsmokers with hpv 16-associated tonsillar carcinomas. Int J Cancer 122(12): 2656-2664, 2008. PMID: 18360824. DOI: 10.1002/ijc.23458

18 Tribius S, Hoffmann AS, Bastrop S, Gorogh T, Haag J, Rocken C, Clauditz T, Grob T, Wilczak W, Tennstedt P, Borcherding A, Petersen $\mathrm{C}$ and Hoffmann M: Hpv status in patients with head and neck of carcinoma of unknown primary site: $\mathrm{Hpv}$, tobacco smoking, and outcome. Oral Oncol 48(11): 1178-1184, 2012. PMID: 22739067. DOI: 10.1016/j.oraloncology.2012.05.022

19 Rhie A, Park WS, Choi MK, Kim JH, Ryu J, Ryu CH, Kim JI and Jung YS: Genomic copy number variations characterize the prognosis of both p16-positive and p16-negative oropharyngeal squamous cell carcinoma after curative resection. Medicine (Baltimore) 94(50): e2187, 2015. PMID: 26683928. DOI: $10.1097 / \mathrm{md} .0000000000002187$

20 Stucken CL, de Almeida JR, Sikora AG, Tong CC and Genden EM: Impact of human papillomavirus and smoking on survival outcomes after transoral robotic surgery. Head Neck 38(3): 380386, 2016. PMID: 25351893. DOI: 10.1002/hed.23915

21 Platek AJ, Jayaprakash V, Merzianu M, Platek ME, Cohan DM, Hicks WL, Jr., Marimuthu SP, Winslow TB, Gupta V, Arshad H, Kuriakose MA, Dibaj S, Marshall JR, Reid ME, Warren GW and Singh AK: Smoking cessation is associated with improved survival in oropharynx cancer treated by chemoradiation. Laryngoscope 126(12): 2733-2738, 2016. PMID: 27346612. DOI: $10.1002 /$ lary.26083

22 Peterson LA, Bellile EL, Wolf GT, Virani S, Shuman AG, Taylor JM and Rozek LS: Cigarette use, comorbidities, and prognosis in a prospective head and neck squamous cell carcinoma population. Head Neck 38(12): 1810-1820, 2016. PMID: 27432208. DOI: 10.1002/hed.24515

23 Kompelli AR, Morgan P, Li H, Harris W, Day TA and Neskey DM: Prognostic impact of high-risk pathologic features in hpvrelated oropharyngeal squamous cell carcinoma and tobacco use. Otolaryngol Head Neck Surg 160(5): 855-861, 2019. PMID: 30526292. DOI: $10.1177 / 0194599818818446$ 
24 Xiao R, Pham Y, Ward MC, Houston N, Reddy CA, Joshi NP, Greskovich JF, Jr., Woody NM, Chute DJ, Lamarre ED, Prendes BL, Lorenz RR, Scharpf J, Burkey BB, Geiger JL, Adelstein DJ and Koyfman SA: Impact of active smoking on outcomes in hpv+ oropharyngeal cancer. Head Neck 42(2): 269-280, 2020. PMID: 31769100. DOI: 10.1002/hed.26001

25 Whiting P, Savovic J, Higgins JP, Caldwell DM, Reeves BC, Shea B, Davies P, Kleijnen J and Churchill R: Robis: A new tool to assess risk of bias in systematic reviews was developed. J Clin Epidemiol 69: 225-234, 2016. PMID: 26092286. DOI: 10.1016/ j.jclinepi.2015.06.005

26 Chen SY, Massa S, Mazul AL, Kallogjeri D, Yaeger L, Jackson RS, Zevallos J and Pipkorn P: The association of smoking and outcomes in hpv-positive oropharyngeal cancer: A systematic review. Am J Otolaryngol 41(5): 102592, 2020. PMID: 32521295. DOI: $10.1016 /$ j.amjoto.2020.102592

27 Hong AM, Martin A, Chatfield M, Jones D, Zhang M, Armstrong B, Lee CS, Harnett G, Milross C, Clark J, Elliott M, Smee R, Corry J, Liu C, Porceddu S, Rees G and Rose B: Human papillomavirus, smoking status and outcomes in tonsillar squamous cell carcinoma. Int J Cancer 132(12): 2748-2754, 2013. PMID: 23180456. DOI: $10.1002 / \mathrm{ijc} .27956$

28 Hawkins PG, Mierzwa ML, Bellile E, Jackson WC, Malloy KM, Chinn SB, Spector ME, Shuman AG, Stucken CL, McLean SA, Bradford CR, Prince ME, Carey TE, Worden FP, Swiecicki PL, Taylor JMG, Wolf GT, Eisbruch A and Casper KA: Impact of american joint committee on cancer eighth edition clinical stage and smoking history on oncologic outcomes in human papillomavirus-associated oropharyngeal squamous cell carcinoma. Head Neck 41(4): 857-864, 2019. PMID: 30775826. DOI: $10.1002 /$ hed.25336

29 Kumar B, Cordell KG, Lee JS, Worden FP, Prince ME, Tran HH, Wolf GT, Urba SG, Chepeha DB, Teknos TN, Eisbruch A, Tsien CI, Taylor JM, D'Silva NJ, Yang K, Kurnit DM, Bauer JA, Bradford CR and Carey TE: Egfr, p16, hpv titer, bcl-xl and p53, sex, and smoking as indicators of response to therapy and survival in oropharyngeal cancer. J Clin Oncol 26(19): 31283137, 2008. PMID: 18474878. DOI: 10.1200/JCO.2007.12.7662

30 Ljokjel B, Haave H, Lybak S, Aarstad HH, Karlsdottir A, Vintermyr OK and Aarstad HJ: The impact of hpv infection, smoking history, age and operability of the patient on diseasespecific survival in a geographically defined cohort of patients with oropharyngeal squamous cell carcinoma. Acta Otolaryngol 134(9): 964-973, 2014. PMID: 24963968. DOI: 10.3109/ 00016489.2014 .927590

31 Maxwell JH, Kumar B, Feng FY, Worden FP, Lee JS, Eisbruch A, Wolf GT, Prince ME, Moyer JS, Teknos TN, Chepeha DB, McHugh JB, Urba SG, Stoerker J, Walline HM, Kurnit DM, Cordell KG, Davis SJ, Ward PD, Bradford CR and Carey TE: Tobacco use in human papillomavirus-positive advanced oropharynx cancer patients related to increased risk of distant metastases and tumor recurrence. Clin Cancer Res 16(4): 12261235, 2010. PMID: 20145161. DOI: 10.1158/1078-0432.CCR09-2350

32 Haughey BH and Sinha P: Prognostic factors and survival unique to surgically treated p16+ oropharyngeal cancer. Laryngoscope 122 Suppl 2: S13-33, 2012. PMID: 22926949. DOI: $10.1002 /$ lary.23493

33 Lassen P, Lacas B, Pignon JP, Trotti A, Zackrisson B, Zhang Q, Overgaard J, Blanchard P and Group MC: Prognostic impact of hpv-associated p16-expression and smoking status on outcomes following radiotherapy for oropharyngeal cancer: The march-hpv project. Radiother Oncol 126(1): 107-115, 2018. PMID: 29100700. DOI: 10.1016/j.radonc.2017.10.018

34 Billfalk-Kelly A, Yu E, Su J, O'Sullivan B, Waldron J, Ringash J, Bartlett E, Perez-Ordonez B, Weinreb I, Bayley A, Bratman SV, Cho J, Giuliani M, Hope A, Hosni A, Kim J, Hansen AR, de Almeida J, Tong L, Xu W and Huang SH: Radiologic extranodal extension portends worse outcome in $\mathrm{cn}+\mathrm{tnm}-8$ stage i human papillomavirus-mediated oropharyngeal cancer. Int J Radiat Oncol Biol Phys 104(5): 1017-1027, 2019. PMID: 30953712. DOI: 10.1016/j.ijrobp.2019.03.047

35 Tran N, Rose BR and O'Brien CJ: Role of human papillomavirus in the etiology of head and neck cancer. Head Neck 29(1): 6470, 2007. PMID: 16823878. DOI: 10.1002/hed.20460

36 Kobayashi K, Hisamatsu K, Suzui N, Hara A, Tomita H and Miyazaki T: A review of hpv-related head and neck cancer. J Clin Med 7(9), 2018. PMID: 30150513. DOI: 10.3390/ jcm7090241

37 Brennan JA, Boyle JO, Koch WM, Goodman SN, Hruban RH, Eby YJ, Couch MJ, Forastiere AA and Sidransky D: Association between cigarette smoking and mutation of the p53 gene in squamous-cell carcinoma of the head and neck. N Engl J Med 332(11): 712-717, 1995. PMID: 7854378. DOI: 10.1056/ nejm199503163321104

38 Jethwa AR and Khariwala SS: Tobacco-related carcinogenesis in head and neck cancer. Cancer Metastasis Rev 36(3): 411-423, 2017. PMID: 28801840. DOI: 10.1007/s10555-017-9689-6

39 Ang KK, Harris J, Wheeler R, Weber R, Rosenthal DI, NguyenTan PF, Westra WH, Chung CH, Jordan RC, Lu C, Kim H, Axelrod R, Silverman CC, Redmond KP and Gillison ML: Human papillomavirus and survival of patients with oropharyngeal cancer. N Engl J Med 363(1): 24-35, 2010. PMID: 20530316. DOI: 10.1056/NEJMoa0912217

40 Granata R, Miceli R, Orlandi E, Perrone F, Cortelazzi B, Franceschini M, Locati LD, Bossi P, Bergamini C, Mirabile A, Mariani L, Olmi P, Scaramellini G, Potepan P, Quattrone P, Ang KK and Licitra L: Tumor stage, human papillomavirus and smoking status affect the survival of patients with oropharyngeal cancer: An Italian validation study. Ann Oncol 23(7): 1832-1837, 2012. PMID: 22115925. DOI: 10.1093/annonc/mdr544

41 O'Sullivan B, Huang SH, Siu LL, Waldron J, Zhao H, PerezOrdonez B, Weinreb I, Kim J, Ringash J, Bayley A, Dawson LA, Hope A, Cho J, Irish J, Gilbert R, Gullane P, Hui A, Liu FF, Chen $\mathrm{E}$ and $\mathrm{Xu} \mathrm{W}$ : Deintensification candidate subgroups in human papillomavirus-related oropharyngeal cancer according to minimal risk of distant metastasis. J Clin Oncol 31(5): 543550, 2013. PMID: 23295795. DOI: 10.1200/jco.2012.44.0164

42 Sobus SL and Warren GW: The biologic effects of cigarette smoke on cancer cells. Cancer 120(23): 3617-3626, 2014. PMID: 25043526. DOI: 10.1002/cncr.28904

43 Warren GW, Sobus S and Gritz ER: The biological and clinical effects of smoking by patients with cancer and strategies to implement evidence-based tobacco cessation support. Lancet Oncol 15(12): e568-580, 2014. PMID: 25439699. DOI: 10.1016/ s1470-2045(14)70266-9

44 House R, Majumder M, Janakiraman H, Ogretmen B, Kato M, Erkul E, Hill E, Atkinson C, Barth J, Day TA and Palanisamy V: Smoking-induced control of mir-133a-3p alters the expression of egfr and hur in hpv-infected oropharyngeal cancer. PLoS One 
13(10): e0205077, 2018. PMID: 30289952. DOI: 10.1371/ journal.pone .0205077

45 Tota JE, Gillison ML, Katki HA, Kahle L, Pickard RK, Xiao W, Jiang B, Graubard BI and Chaturvedi AK: Development and validation of an individualized risk prediction model for oropharynx cancer in the us population. Cancer 125(24): 44074416, 2019. PMID: 31454434. DOI: $10.1002 / \mathrm{cncr} .32412$

46 Prigge ES, Arbyn M, von Knebel Doeberitz M and Reuschenbach M: Diagnostic accuracy of p16(ink4a) immunohistochemistry in oropharyngeal squamous cell carcinomas: A systematic review and meta-analysis. Int J Cancer 140(5): 1186-1198, 2017. PMID: 27859245. DOI: $10.1002 / \mathrm{ijc} .30516$
47 Qureishi A and Winter S: Letter to editor: Current and future techniques for human papilloma virus (hpv) testing in oropharyngeal squamous cell carcinoma. Eur Arch Otorhinolaryngol 274(12): 4259, 2017. PMID: 28744662. DOI: $10.1007 / \mathrm{s} 00405-017-4675-8$
Received October 4, 2020

Revised November 27, 2020

Accepted December 4, 2020 